\title{
JUURNAL.RU
}

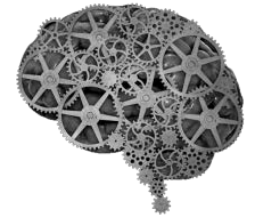

COMPANY GROUP "INTELLEKT"

Дмитриев А.С., Должиков И.С. Санкт-Петербургский Государственный Архитектурно-строительный Университет Санкт-Петербург, Россия

doi: 10.18411/lj2016-5-1-04

\section{Оптимизация системы охраны труда в современном мостостроении}

Современное мостостроение в России открывает новые ориентиры перед непосредственными его участниками. $\mathrm{B}$ рамках стесненных условий финансирования, но одновременно с этим - увеличения спроса в качественном строительстве объектов транспортной инфраструктуры, основное место среди которых занимают искусственные сооружения, порой происходят нарушения не только в сфере качества работ или производственных процессов, но и нарушения требований охраны труда. Выделение средств на выполнение работ многими компаниями зачастую не предполагает затрат на этот немаловажный фактор строительства. В чем причина этой проблемы? Чтобы ответить на этот вопрос необходимо обратить внимание на следующий факт: до 01.01.2015г. в случае нарушения законодательства о труде и об охране труда ответственность должностных лиц составляла от 1000 до 5000 рублей, а юридических от 30000 до 50000 рублей. В результате чего, у некоторых работодателей сложилось устойчивое мнение о том: «что мероприятия по охране труда можно не реализовывать, а в случае проведения проверочных мероприятий в отношении компании или расследования несчастных случаев на производстве легче и проще заплатить штраф...» При участии в тендерных конкурсах, руководители многих компаний не включают в расходы статьи, связанные с реализацией мероприятий по охране труда: приобретение специальной одежды и средств индивидуальной защиты, организация проведение медосмотров для работников, 
направление персонала на обучение по охране труда, тем самым подвергая своих работников воздействию вредных, а порой и опасных факторов производственной среды.

И это продолжалось бы и сейчас, ведь как сказал Карл Маркс: «бытие определяет сознание», но в связи с изменениями норм законодательства в области охраны труда с 01.01.2015г. (обратимся к статье 5.27.1 «Нарушение государственных нормативных требований охраны труда, содержащихся в федеральных законах и иных нормативных правовых актах Российской Федерации» кодекса Российской Федерации об административных правонарушениях, в которой определена ответственность должностных и юридических лиц за нарушение требований охраны труда), ситуация несколько изменилась. С указанной даты работодатели волей-неволей вынуждены обращать внимание на этот фактор строительного процесса.

При условии того, что специалист в области охраны труда (до 2013г. инженер по охране труда) сейчас есть почти во всякой крупной строительной организации, не всегда работодатель отдает четкий отчет о месте этого человека в компании и его роли. Отношение к такому специалисту, как к чему-то побочному, «для галочки», может повлиять пагубно на рабочий процесс. К сожалению, надо признать, что и некоторые люди на должности специалиста в области охраны труда не всегда настойчивы в выполнении своих должностных обязанностей. Данные специалисты порой не доводят до руководителей организаций необходимость реализации мероприятий по охране труда, а также возможные последствия для компании в случае не реализации таковых. В результате такой халатности (порой обоюдной), в случае несчастного случая на производстве происходит полная неразбериха. Для исключения подобных случаев руководству компании необходимо понять роль специалиста по охране труда в компании, определить перечень его прав и обязанностей. Для решения данной задачи работодателю (специалисту отдела кадров) необходимо ознакомиться с приказом Министерства труда и социальной защиты Российской 
Федерации от «4» августа 2014 г. №524н «Профессиональный стандарт «Специалист по охране труда». В данном приказе подробно определены: общие сведения профессиональной деятельности, описание трудовых функций, перечень необходимых умений и знаний, требования к стажу работы и образованию. Также при поиске специалиста по охране труда работодателю необходимо изучить личностные качества будущего сотрудника. Кандидат должен обладать определенными качествами характера: он должен быть волевым, настойчивым, уметь ставить перед собой задачи и выполнять их. Специалист по охране труда должен уметь аргументированно и настойчиво разъяснить руководителю компании необходимость проведения мероприятий по охране труда. Рационально составлять планы реализации мероприятий и сметы расходов, чтобы не создавать «нагрузок» на бюджет компании.

В заключении хочется отметить, что динамика улучшения в области реализации мероприятий по охране труда в современном мостостроении есть. Несмотря на то, что в нашей стране, в настоящее время, преобладает нестабильная экономическая обстановка, почти в каждой компании есть должность специалиста по охране труда. Конечно, в первую очередь это связано c изменениями в законодательстве, но есть надежда, что постепенно мероприятия по охране труда в компаниях будут реализовываться не только изза возможности применения штрафных санкций, а и в связи с осознанием работодателями важности приоритета сохранения жизни и здоровья сотрудников в процессе осуществления трудовой деятельности.

\section{Литература:}

1. Кодекс Российской Федерации об административных правонарушениях

2. Приказ Министерства труда и социальной защиты РФ от 4 августа 2014 г. №524н «Об утверждении профессионального стандарта «Специалист в области охраны труда» 